\title{
Main Trends of Foreign Trade of PRC during the Eleventh Five-Year Plan in Terms of Target Intensification of Trade and Economic Relations with Russia
}

\author{
Mikhail N. Kulapov
}

Yuri G. Odegov

\section{Maxim A. Ponomarev}

Russian economic university of a name of G. V. Plekhanov, 117997, Russia, Moscow, Stremyanny lane, 36

Doi:10.5901/mjss.2015.v6n6s3p19

\section{Abstract}

Economic relations between Russia and China gradually enter into the most active phase, primarily due to the successful results of the official visits of heads of state and government. Trade between the countries become more active increasingly that contributes to the development of economic relations in general. In order to understand the reasons for this development against the background of the ongoing growth of the Chinese economy, the focus of attention in this article is the foreign trade of China as the dominant component of the activity of economic relations with other countries. The article presents an analytical summary of the results and prospects of foreign trade of the People's Republic of China (PRC) according to the Eleventh FiveYear Plan results (2005-2010). Besides formulated general conclusions and trends, such indicators as the trade balance, the global, sectoral, regional, commodity structure of exports and imports are analyzed detailed, and also the reasons for these trends in foreign economic activity of the country are investigated. Among the analyzed basic forms of foreign trade it is considered tolling system and its place in the trade of goods. Indicators of foreign trade products and services are analyzed separately. The basic trend in the development of trade and economic relations between China and Russia is investigated.

Keywords: foreign trade, total turnover, trade balance, industrial, commodity and geographical structure.

\section{Introduction}

From the point of view of trends of changes in total sales of foreign trade, the development in China during the years of the Eleventh Five-Year Plan (2005-2010) was in strict correspondence with "Concept of foreign economic policy for the period to 2010" approved by State Council of PRC on August 24, 2006.

Results of the five-year development suggests that the tasks, namely by 2010 bring volume of foreign trade to the level of $\$ 2.3$ trillion (at an average annual growth rate of $10 \%$ ), and trade in services - up to $\$ 400$ billion (at an average annual growth of 20\%) were exceeded. In particular, this was evident in indicators such as foreign trade and trade in goods. However, in trade in services, the planned growth indicators could not be reached (Beijing Review. Vol. 1-17. 2007).

China's foreign trade turnover reached $\$ 2$ trillion 972.76 billion with an average annual growth rate of $18.2 \%$. And the preponderance of exports over imports continued: the average annual growth rate of exports and imports were respectively 19\% and 17.3\% (The Russian-Chinese trade and economic cooperation in 2011, http://www.eurasian commission.org/).

As is known, the steady increasing of foreign trade volumes has already provided China the world leader in 2009 in terms of export and the second place in import volumes. Subsequently, China has strengthened the leading position when national exports grew by more than $31.3 \%$, while the volume of Chinese imports increased by $38.7 \%$. According to the latest index, China is now second only to Japan.

If one talk about the balance of export-import operations in the structure of world trade of China, then there is an obvious multidirectional dynamics of the trade balance. Until 2008, there was a moderate increase in its surplus. In subsequent years, the State Council of the PRC was able to solve an important strategic task - to provide risk reduction for the economic development of the trade surplus, which in 2008 overcame the reference level at 10\%. Already in 20092010 measures adopted by the Chinese government to accelerate import volumes helped reduce the trade surplus to "comfortable" for the Chinese economy to the level of $6 \%$ of the total foreign trade volume (The Russian-Chinese trade and economic cooperation in 2011, http://www.eurasiancommission.org/). 


\section{Methods and Materials}

\subsection{Sectoral structure}

Sectoral structure of China's turnover was characterized by the following features:

- increase in total exports of industrial products' share from $93.6 \%$ in 2005 to $94.82 \%$ in 2010 ,

- $\quad$ increase of the share of machinery and equipment and high-tech products by 3.3 and 2.8 percentage points above the level in 2005

- increase of the share of primary production in total imports, which grew from $22.11 \%$ in 2005 to $31.01 \%$ in 2010 (Lee-Jay Cho and Chang Jae Lee (2014).)

\subsection{Geographic structure}

Geographic structure of China's total sales was characterized by a decrease in share of Asian countries (-4.1\%) and North America (-2.0\%) and an increase in the shares of European countries (+0.9\%), Latin America (+2.7 \%), Africa $(+1.5 \%)$ and Oceania $(+1.1 \%)$ (The Russian-Chinese trade and economic cooperation in 2011, http://www.eurasian commission.org/).

Table 1 - Dynamics of world regions' position in China's foreign trade, \%

\begin{tabular}{|l|c|c|c|c|c|c|}
\hline Regions & \multicolumn{2}{|c|}{ Share in China's turnover } & \multicolumn{2}{|c|}{ Share in China's export } & \multicolumn{2}{c|}{ Share in China's import } \\
& 2005 & 2010 & 2005 & 2010 & 2005 & 2010 \\
Asian countries & 56,8 & 52,7 & 48,1 & 46,4 & 66,9 & 59,8 \\
European countries & 18,4 & 19,3 & 21,7 & 22,5 & 14,6 & 15,6 \\
North America & 16,2 & 14,2 & 22,9 & 19,4 & 8,5 & 8,4 \\
Latin America & 3,5 & 6,2 & 3,1 & 5,8 & 4,1 & 6,5 \\
Africa & 2,8 & 4,3 & 2,5 & 3,8 & 3,2 & 4,8 \\
Oceania & 2,2 & 3,3 & 1.7 & 2,1 & 2,7 & 4,7 \\
\hline
\end{tabular}

(Statistical Yearbook of China, 2006 - 2012. China Statistical Yearbook, http://www.stats.gov.cn/.)

Some other results of the China's foreign trade development in 2005-2010 deserve attention:

- share of enterprises with foreign capital participation in the foreign trade of China declined from $58.5 \%$ to 53.83\%;

- $\quad$ share of Chinese non-state enterprises in foreign trade turnover increased from $15.8 \%$ to $25.14 \%$;

- $\quad$ share of Chinese state-owned enterprises fell from $25.7 \%$ to $21.02 \%$.

Analyzing foreign trade in goods over the past five years, Chinese experts identify the following major trends in its development:

1. Improving foreign trade structure, including the commodity structure of exports, increasing the competitiveness of Chinese products in the international market.

2. Acceleration in increase of imports volume, to ensure offset development of foreign trade balance.

3. Improvement of the regional structure of foreign trade, to ensure a faster growth in trade with the countries with the new emerging economies and developing countries.

In trade in goods, a major share of China's foreign trade turnover (80-90\%) falls on such forms as ordinary trade and tolling trade. Analysis of the development of these forms of trade in Eleventh Five-Year Plan suggests several important conclusions.

Firstly, it is outlined a positive trend for the effective balance of different forms of trade, namely: regular trade maintained stable positive trend, at the same time the volume of tolling trade reduced as well as its share in the foreign trade (both exports and imports) .

In 2010, the share of tolling trade in total foreign trade of China has reached a historical minimum $-38.94 \%$, while the share of ordinary trade - a historical maximum of $49.85 \%$

Secondly, in the five-year period, there was a clearly trend of the excess of exports over imports in the implementation of tolling trade, which contributed to the accelerated formation of trade surplus compared with the ordinary form of trading. The year 2009 and 2010 were particularly illustrative, when in the framework of ordinary trade red ink was formed, and within the tolling trade there was a steady growth in the trade surplus.

Thirdly, consistent decline in tolling trade has had a positive impact on reducing the degree of China's depending 
on foreign trade.

Depending on degree of dependence upon foreign trade (DDFT) - a figure (usually for 1 year) of foreign trade share in the total income of a particular country, or its share in GDP. DDFT can be calculated using the formula:

$$
D D F T=\frac{F T T}{G D P} \cdot 100 \%
$$

where FTT - foreign trade turnover, GDP - gross domestic product.

In addition, to assess foreign trade turnover dependence such indicators as the degree of dependence on exports (DDE) and the degree of dependence on imports (DDI) are also important, this can also be calculated by the formulas:

$$
\begin{aligned}
& D D E=\frac{\text { Exportvolume }}{G D P} \cdot 100 \% \\
& D D I=\frac{\text { Im portvolume }}{G D P} \cdot 100 \%
\end{aligned}
$$

So, if in 2006 the degree of China's dependence on foreign trade peaked in $66.9 \%$, while in subsequent years it declined steadily and by the end of 2010 reached a historic minimum of $49.0 \%$.

Fourthly, the development of tolling forms of trade was accompanied by increased degree of processing of goods made on commission, increased opportunities for bundling within the country, increasing the degree of localization of production, stimulation of growth of industrial development.

Statistical data showing that over $60 \%$ of China's foreign trade during the Eleventh Five-Year Plan is exported, characterizing the Chinese economy as export-oriented. The main problems which Chinese exporters tried to solve in 2005-2010, was increasing of exports volume of industrial products with high extra cost, which include, first and foremost, machinery and electrical products, textiles ranged, as well as high-tech products (Foreign trade information portal of The Ministry of Economic Development of the Russian Federation, http://www.ved.gov.ru/exportcountries/cn/about_cn/ved_ $\mathrm{cn} /)$.

But the main result of the 2005-2010 years was the increase in the total share of Chinese exports of industrial products from $93.6 \%$ to $94.82 \%$.

With regard to changes in the industrial structure of Chinese imports, the characteristic feature of Chinese imports in 2005-2010, along with increases in volume, was an increase in the share of imported products of primary processing, namely:

- $\quad$ raw materials for food industry;

- beverages and tobacco;

- raw materials for non-food industry;

- $\quad$ natural energy;

- vegetable and animal oils.

Another important trend was the increase in the total import share of China's capital-intensive and scienceintensive products. It is allow introducing advanced technologies in traditional industries, making re-equipment, expanding production, creating new businesses, oriented on exports.

Improvement of the regional structure of foreign trade, to ensure a faster growth in trade with the countries of the

\begin{tabular}{|c|c|c|c|c|c|c|}
\hline Countries & $\begin{array}{c}2008 \\
\text { Volume (million dollars) }\end{array}$ & Increase (\%) & $\begin{array}{c}2009 \\
\text { Volume (million dollars) }\end{array}$ & Increase (\%) & $\begin{array}{c}2010 \\
\text { Volume (million dollars) }\end{array}$ & Increase (\%) \\
\hline Total & 2561632,05 & 17,8 & 2207218,52 & $-13,9$ & 2972761,81 & 34,7 \\
\hline U.S.A. & 333737,63 & 10,5 & 298258,77 & $-10,6$ & 385341,35 & 29,2 \\
\hline Hong Kong & 203666,09 & 3,3 & 174945,01 & $-14,1$ & 230275,47 & 31,8 \\
\hline The Republic of Korea & 186112,92 & 16,2 & 156231,59 & $-16,0$ & 207170.59 & 32,6 \\
\hline Australia & 59636,96 & 36,1 & 60084,35 & $+0,7$ & 88092,07 & 48,5 \\
\hline Malaysia & 53469,45 & 15,2 & 51962,63 & $-3,0$ & 74215,41 & 42,8 \\
\hline Brazil & 48497,27 & 62,2 & 42399,50 & $-12,9$ & 62549,56 & 47,5 \\
\hline India & 51780,49 & 34,0 & 43380,85 & $-16,3$ & 61759,96 & 42,4 \\
\hline Singapore & 52435,61 & 10,5 & 47863,00 & $-8,8$ & 57057,64 & 19,2 \\
\hline Italy & 38255,70 & 21.9 & 31263,91 & $-18,3$ & 45151,32 & 44,5 \\
\hline
\end{tabular}
new emerging economies and developing countries.

Table 2 - Dynamics of China's foreign trade with major trading partners in the outside world Xin \& Ponkratova (2008) 
Data in Table 2 indicate that the growth rate of trade between China and the so-called new emerging economies (the BRICS countries) significantly exceeded the average growth rate of the developed countries (The U.S.A., Japan, Germany).

Among the BRICS countries the first place by the average annual rate of growth of trade volume with China is belong to Brazil (36.0\%), than India (31.0\%) and Russia (20.9\%) respectively.

Among developed countries, the first place by the annual average growth rate of trade with China belongs to the U.S.A. (19.0\%), than Germany (18.3\%) and Japan (10.9\%) respectively.

If one analyze the foreign trade of China in the associations, by the end of 2010 it can be noted that the largest trade partners of China were Asian countries, which share was $\$ 1$ trillion 566.67 billion (+33.7\% compared to 2009). European countries had the share of $\$ 573.10$ billion (34.3\%), North America - $\$ 422.84$ billion (+28.9\%), Latin America $\$ 183.07$ billion (+50.2\%), Africa - $\$ 126.91$ billion (+39.4\%), Oceania $-\$ 98.78$ billion (+46.1\%).

In the framework of international regional integration association, trade of China amounted to: APEC countries - \$1 trillion 907.41 billion (+34.7\%), EU countries had $\$ 479.71$ billion (+31.8\%), ASEAN - \$292.77 billion (+37.5\%).

From trends in trade in products it is expedient to proceed to the analysis and identification of trends in foreign trade in services.

After 2005, trade in services in the PRC had a definite growth dynamics, but on an annual growth rate it was behind the growth dynamics of the trade in products: the share of trade in services as a whole increased from $11.05 \%$ in 2005 to $12.99 \%$ by the end of 2009 and rather decreased by the middle of 2010 - to $12.05 \%$. At the same time, the share of imports in the structure of trade in services is still at a high level - up to $55.16 \%$ by the end of 2009 and to $53.52 \%$ by the middle of 2010.

Foreign trade in services in China traditionally has the red ink - and although by 2007 this figure decreased, by the end of 2009 it showed the growth again. In the first half of 2010, once again there is a tendency to reduce the red ink of China's foreign trade in services.

In 2005-2010, in the structure of trade in services in China's foreign trade tourism services were at the first place in the first half of 2010 , it accounted for $27.97 \%$. The second position in foreign trade volume in services belongs to transport services, its share in the 1st half of 2010 was $26.80 \%$. In this sector, there is a tendency to reduce the share of total trade in services.

In the first half of 2010 there was an increase in China's foreign trade consulting services - to $\$ 17.00$ billion $(+19.60 \%)$, the share of this type of services accounted for $10.26 \%$

In trade in construction services in the period from 2005 to 2010, the volume of provided services was also increasing at steady rate, which provided the stable fourth position in the overall volume of provided services.

\subsection{Analysis of foreign trade development between China and Russia}

Analysis of foreign trade development between China and Russia in the past five years shows that it is planned a steady trend towards the development of foreign economic relations between the two countries, and spasmodic dynamics indicates transition stage of the two countries in the economic sphere. The annual growth rate of foreign trade volume in 2010 amounted to $20.9 \%$, which is higher by 2.7 percentage points than the average growth rate of the total volume of China's foreign trade (+18.2\%). With an average annual growth of China's exports to Russia amounted to $30.4 \%$, which is higher by $11.4 \%$ than the growth rate of China's total exports (+19.0\%). The annual growth rate of Chinese imports from Russia amounted to $15.3 \%$, or lower by 2.0 percentage points than the growth rate of China's total imports $(+17.3 \%)$.

Over the past 5 years, Russia's share in the total foreign trade volume of China decreased from $2.05 \%$ in 2005 to $1.86 \%$ in 2010 . An average annual rate of decline was negligible and amounted to $0.03 \%$ (Monthly customs collections of China, 2005 - 2010, http://english.customs.gov.cn/).

The trade balance between China and Russia in the period 2005-2010 showed mixed trends. Up to 2007, there was a moderate reduction in the trade deficit of China. In 2007-2008 period was marked by a sharp increase in the trade surplus for China's benefit. During the crisis of 2009, imports from Russia to China once again exceeded the volume of China's exports to our country. This is due to a sharp drop in energy and industrial metal prices, which are the basis of Russian exports, so that China has increased the volume of imports of these products to ensure sustainable development of key sectors of its economy. In 2010, however, China again increased its exports to Russia, securing a positive trade balance.

Russia's position in the geographical structure of the total Chinese trade in 2005-2010 has undergone significant changes. If until 2009 Russia was among the ten largest trade partners of China, ranking at the 7th place in 2007, and in 2008 - at the 8th position, while in 2009 it dropped to the 14th place among the major trading partners of China (Wilson 
Jeanne (2004)). At the same time Russia passed ahead of the other BRICS countries - India and Brazil. In 2010, Russia was able to move to the 13 position in the rating, but to surpass the other BRICS countries by volume of trade with China it couldn't (Statistical Yearbook of China, 2006 - 2012, http://www.stats.gov.cn/).

So, it was found that the Sino-Russian trade is different from China's foreign trade in the whole by dynamics and the degree of reaction to the economic crisis. As a result of this crisis, there was a deeper drop in Sino-Russian trade at both in the country and at interregional levels than in China's foreign trade in general. If one analyze the structural changes in China's exports and imports in trade with Russia (The Russian-Chinese trade and economic cooperation in 2011, http://www.eurasiancommission.org/), it can be noted that the structural changes were not only the most significant (compared with China's trade in general), but growing trend of rise of raw materials dependence of Russian exports.

\subsection{Sectoral structure of Sino-Russian trade}

Sectoral structure of Sino-Russian trade turnover was characterized by a consistent increase in Chinese exports to the Russian share of industrial production (chemical products, metals and metal products, textiles, textile products, footwear, machinery, equipment and vehicles) from $16.3 \%$ in 2005 to $19.2 \%$ in 2010. The share of engineering products reached $34.4 \%$, which is higher by 14.3 percentage points than in 2005 . Also a typical trend in the industrial structure was the increase in the share of products of primary processing (agricultural raw materials, mineral products, wood and pulp) in Chinese imports from Russia, which grew from 21.1\% in 2005 to 24.5\% in 2010 (Jing Huang, Alexander Korolev (2015), Bellacqua James (2010)).

Analysis of institutional factors in the development of Sino-Russian trade cooperation has revealed the existence of a regulatory mechanism implemented at three levels:

- international agreements;

- national policies and programs affecting the separate spheres of foreign economic cooperation between China and Russia;

- international inter-regional cooperation agreements.

In addition, several institutions of interstate and inter-regional cooperation in the field of trade in goods and services, investment and other activities were established.

Comparative analysis of the involvement of Russia and China in international economic relations (Xin \& Ponkratova, (2008); Voskresenskii A. (2003)) revealed their high involvement of both countries into the world economy, primarily by exports, which indicates the opportunities that arise for mutual trade as a result of complementary economies. The estimate of the degree of mutual integration of China and Russia in the sphere of trade allowed concluding that both countries at initially trade cooperation level were characterized by higher rates of trade integration than at present.

It is necessary to emphasize the strategic role of the northeast of China, especially in Heilongjiang Province, in the development of Sino-Russian trade and economic cooperation. In the north-eastern region there is about a quarter of the total Sino-Russian trade. The biggest part of the mutual trade belongs to the province of Heilongjiang.

\section{Concluding Remarks}

In general, the political context of relations between the two countries a number of signed international agreements and documents reflects a continuation in the future of the rising trend in the development of Sino-Russian trade and economic relations. However, it should be noted significant reserves for intensification of bilateral relations. First of all, it should be formed on a parity basis a training system (with knowledge of Chinese and Russian) to meet the needs of the two economies, including the conclusion and performance of business contracts at all levels of trade and economic cooperation between Russia and China.

\section{References}

The Russian-Chinese trade and economic cooperation in 2011. The Trade Mission of the Russian Federation in the People's Republic of China. Access mode: http://www.eurasiancommission.org/.

Zhao, Xin \& Ponkratova, L.A. (2008). Foreign Trade of China: features of the development after the WTO accession and cooperation with Russia. Herald of The Amur State University. A series of "Natural sciences and economics." Issue 41.

Foreign trade information portal of The Ministry of Economic Development of the Russian Federation http://www.ved.gov.ru/export countries/cn/about_cn/ved_cn/. 
Monthly customs collections of China, 2005 - 2010. №12. http://english.customs.gov.cn/ Statistical Yearbook of China, 2006 - 2012. China Statistical Yearbook, http://www.stats.gov.cn/.

Wilson Jeanne (2004). Strategic Partners: Russian-Chinese Relations in the Post-Soviet Era. N.Y. Taylor \& Fracis Group. pp. 296.

Voskresenskiĭ A. (2003). Russia and China: A Theory of Inter-state Relations. N.Y. Taylor \& Fracis Group. -278 p.

Bellacqua James (2010). The Future of China-Russia Relations/ University Press of Kentucky. $-372 \mathrm{p}$.

Jing Huang, Alexander Korolev (2015). International Cooperation in the Development of Russia's Far East and Siberia. Palgrave Macmillan. pp. 280.

Beijing Review. Vol. 1-17. 2007.

Lee-Jay Cho and Chang Jae Lee (2014). Financing Economic Integration and Functional Cooperation for Northeast Asia: Toward a Northeast Asian Economic Community. Korea Institute for International Economic Policy (South Korea). pp. 285. 